\title{
Perspectives on Regulating Systemic RisK ${ }^{1}$
}

\section{Steven L. Schwarcz ${ }^{2}$}

I. General PeRsPectives on RegUlating SYSTEMIC Risk .............................................. 3

A. Systemic Shocks are Inevitable................................................................................. 3

1. Certain Inevitable Market Failures can Increase Systemic Risk.................................... 4

2. In a Changing Financial System, Regulation can Lag Reality ..................................... 6

3. Excessive Corporate Risk-taking can Trigger Systemic Shocks ..................................... 7

B. Regulation therefore Should Protect the Financial System Against the Impact of

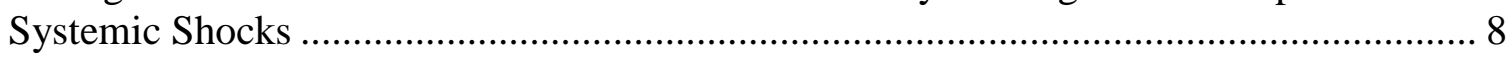

II. PERSPECTIVES ON REGULATING EXCESSIVE CORPORATE RISK-TAKING, A LEADING TRIGGER OF SYSTEMIC SHOCKS

A. Why Have So Few Managers been Prosecuted for Excessive Corporate Risk-taking that Led to the Financial Crisis?

1. Systemic Risk is Complicating What Risk-Taking is 'Excessive'................................. 13

2. Decisionmaking is Becoming More Decentralized ....................................................... 14

3. The Law Increasingly is Lagging Financial Innovation................................................ 15

4. Systemic Harm is Limiting Proof of Causation .......................................................... 16

5. Shrinking of Resources is Tightening Prosecutorial Risk-Reward Assessment............. 16

B. How Else Could Excessive Corporate Risk-taking be Regulated? ............................... 17

1. Imposing Firm-level Liability is Not a Credible Deterrent .......................................... 18

2. Should there be a Public Governance Duty?.............................................................. 20

3. Should Limited Liability Remain the Norm, Especially for Shadow-Banking Firms? . 23

4. Should Ring-fencing be used to Control Corporate Risk-taking? ................................. 24

5. Should Regulation Limit Too-Big-to-Fail Firms? ......................................................... 26

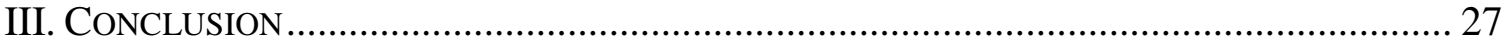

${ }^{1}$ Copyright $@ 2016$ by Steven L. Schwarcz.

${ }^{2}$ Stanley A. Star Professor of Law \& Business, Duke University School of Law (schwarcz@law.duke.edu), and Senior Fellow, the Centre for International Governance Innovation (CIGI). I thank Theodore D. Edwards and Tashi Sun for valuable research assistance. Support is provided in part by a Fuller-Purdue grant. Portions of this chapter are based on Professor Schwarcz's articles, including 'Regulating Financial Change: A Functional Approach’ (2016) 100 Minnesota Law Review $<$ http://ssrn.com/abstract=2469467> (forthcoming) accessed 24 September 2015; Steven L Schwarcz, 'Excessive Corporate Risk-Taking and the Decline of Personal Blame' (2015) 65 Emory Law Journal <http://ssrn.com/abstract=2553511> (forthcoming) accessed 24 September 2015. 
This chapter attempts to provide useful perspectives on regulating systemic risk. First, it argues that systemic shocks are inevitable. Accordingly, regulation should be designed not only to try to reduce those shocks but also to protect the financial system against their unavoidable impact. This could be done, the chapter explains, by applying chaos theory to help stabilize the financial system.

The chapter then focuses on trying to prevent excessive corporate risk-taking, which is one of the leading triggers of systemic shocks and widely regarded to have been a principal cause of the financial crisis. ${ }^{3}$ It begins by inquiring why so few managers have been prosecuted for the excessive corporate risk-taking that led to the financial crisis. ${ }^{4}$ Targeting managers in their personal capacity would be a greater deterrent to excessive risk-taking than fallbacks such as imposing firm-level liability. ${ }^{5}$ The chapter finds, however, a host of reasons why managerial prosecution is not-and is unlikely to

${ }^{3}$ See, e.g., Financial Crisis Inquiry Commission, The Financial Crisis Inquiry Report: Final Report of the National Commission on the Causes of the Financial and Economic Crisis in the United States (2011) <http://fcic-static.law.stanford.edu/cdn_media/fcicreports/fcic_final_report_full.pdf> accessed 24 September 2015 (identifying excessive risk-taking as a primary cause of the financial crisis); 'The Origins of the Financial Crisis: Crash Course' The Economist (7 September 2013) $<$ http://www.economist.com/news/schoolsbrief/21584534-effects-financial-crisis-arestill-being-felt-five-years-article> accessed 24 September 2015 (identifying excessive risk-taking as one of three causes of the financial crisis, the other causes being irresponsible lending and regulators being asleep at the wheels); Jacob Lew, 'Let's Leave Wall Street's Risky Practices in the Past' Washington Post (9 January 2015) (in which U.S. Treasury Secretary Lew repeatedly attributes the financial crisis to "excessive risks taken by financial” firms).

${ }^{4}$ See Part II.A.

${ }^{5}$ See, e.g., Mary Jo White, U.S. SEC Chair, 'Deploying the Full Enforcement Arsenal' (Council of Institutional Investors Fall Conference, Chicago,,2013)

<http://www.sec.gov/News/Speech/Detail/Speech/1370539841202\#.VE7m_iJ4pK4> accessed 24 September 2015; Claire A Hill \& Richard W Painter, 'Why SEC Settlements Should Hold Senior Executives Liable’ New York Times (29 May 2012) $<$ http://dealbook.nytimes.com/2012/05/29/why-s-e-c-settlements-should-hold-seniorexecutives-liable/> accessed 24 September 2015 (observing two reasons for this greater deterrence: that economic actions taken against individuals not only require them to pay out of their only pockets but also impose reputational costs - a form of shaming - causing the individuals to lose social standing and jeopardizing their ability to continue working in the financial sector). 
become-a credible deterrent. Finally, the chapter examines how else excessive risktaking could, and should, be regulated. ${ }^{6}$

\section{General Perspectives on Regulating Systemic RisK ${ }^{7}$}

Perfect markets would never, in theory, need external regulation. But markets, including financial markets, are imperfect, so government intervention is sometimes necessary. Traditional financial regulation focuses on maximizing economic efficiency within the financial system of the system's underlying economic functions- the provision, allocation, and deployment of capital. However, these functions can be carried out efficiently only when the financial system itself operates efficiently as a network. Systemic risk regulation (sometimes called macroprudential regulation) serves to protect the financial system’s ability to so operate.

As explained below, any regulatory framework for achieving that objective will be imperfect and have tradeoffs. That is because systemic shocks are inevitable and we do not yet know enough about how such shocks spread to prevent their transmission. Systemic risk regulation therefore should include a focus on stabilizing parts of the financial system afflicted by those shocks.

\section{A. Systemic Shocks are Inevitable}

For at least three reasons, systemic shocks are inevitable. First, some of the inevitable market failures that impair efficiency can also increase systemic risk. Second, the financial system is constantly changing, and therefore regulation will occasionally lag financial reality. Finally, as examined in detail in Part II of this chapter, regulation does

\footnotetext{
${ }^{6}$ See Part II.B.

7 This discussion is based on Steven L Schwarcz \& Iman Anabtawi, 'Regulating Systemic Risk: Towards an Analytical Framework' (2011) 86 Notre Dame Law Review 1349; Steven L Schwarcz, 'Regulating Complexity in Financial Markets' (2009) 87 Washington University Law Review 211; and Steven L Schwarcz, 'Systemic Risk' (2008) 97 Georgetown Law Journal 193.
} 
not adequately limit the incentives of corporate managers to engage their firms in risktaking that could have systemic consequences.

\section{Certain Inevitable Market Failures can Increase Systemic Risk}

Some of the inevitable market failures that impair efficiency can also increase systemic risk. For example, increasing financial complexity has created information failures that even disclosure cannot remedy. ${ }^{8}$ The task of deciphering a prospectus, hundreds of pages long and full of detailed technical and legal phraseology, is usually burdensome even for the most sophisticated institutional managers-so they often overrely on credit ratings, especially if other financial institutions are investing in the same types of securities. Bounded human rationality, including cognitive limitations and time horizons for decisionmaking, also limits the effectiveness of even otherwise ideal laws. ${ }^{9}$ And the increasing dispersion of financial risk is undermining monitoring incentives. $^{10}$

In combination, these information failures can increase systemic risk in several ways. Inadequate transparency and inadequate monitoring can cause firms to overinvest, leading to systemic shocks such as price bubbles and bankruptcies. Inadequate transparency (as we saw with some of the more complex asset-backed securities), especially when coupled with bounded rationality, can lead to panics, causing financial market prices to collapse.

\footnotetext{
${ }^{8}$ See Steven L Schwarcz, 'Disclosure’s Failure in the Subprime Mortgage Crisis’ (2008) Utah L Rev 1109 (observing that investors did not fully understand certain complex asset-backed securities notwithstanding securities-law compliant disclosure; and arguing that disclosure alone is inadequate to remedy asymmetric information and other information failures); Steven L Schwarcz, 'Rethinking the Disclosure Paradigm in a World of Complexity' (2004) University of Illinois Law Review 1.

${ }^{9}$ See, e.g., Iman Anabtawi \& Steven L Schwarcz, 'Regulating Systemic Risk: Towards an Analytical Framework’ (2011) 86 Notre Dame Law Review 1349.

${ }^{10}$ Steven L Schwarcz, 'Marginalizing Risk’ (2012) 89 Washington University Law Review 487.
} 
Another type of market failure-principal-agent failure-can also increase systemic risk. This failure is typified by a manager — and increasingly with financial complexity, including a middle manager such as an analyst—sacrificing a firm's longterm interests to make short-term personal gains. For example, senior analysts may recommend that their firms invest in highly leveraged (and thus risky) securities, such as ABS CDOs, in order to make personal bonuses. They "earn” the bonuses because these are high-yield securities with ostensibly minimal risk, as evidenced by heuristic ${ }^{11}$ models such as $\mathrm{VaR}^{12}$ and rating-agency ratings. The models can obscure the reality that the risk may be relatively low but, if it occurs, the consequences are very high-a so-called "black swan” event. Senior executives often lack the technical background, and the time, to second-guess the models.

Principal-agent failure is theoretically, although less pragmatically, susceptible to legal solutions. The obvious solution is to require systemically important firms to pay their managers under longer-term compensation arrangements, possibly including clawbacks. To some extent, this is now beginning to be done in the United States. But it still has several flaws. One is that existing regulation focuses on senior executive compensation, whereas the greater problem may lie with middle manager compensation. Middle managers are almost always paid under short-term compensation schemes, misaligning their interests with the long-term interests of the firm. ${ }^{13}$ Complexity exacerbates this problem by increasing information asymmetry between technically sophisticated middle managers and the senior managers to whom they report. ${ }^{14}$ Another

\footnotetext{
${ }^{11}$ I use this term in its broad sense, to refer to simplifications of reality that allow us to make decisions in spite of our limited ability to process information.

${ }^{12} \mathrm{VaR}$, or Value at Risk, is a measure of the probable loss in an investment portfolio given certain parameters such as time and probability of loss.

${ }^{13}$ See Steven L Schwarcz, 'Conflicts and Financial Collapse: The Problem of SecondaryManagement Agency Costs’ (2009) 26 Yale Journal on Regulation 457.

${ }^{14}$ For example, as the VaR model for measuring investment-portfolio risk became more accepted, financial firms began compensating secondary managers not only for generating profits but also for generating profits with low risks, as measured by VaR. See, e.g., Philippe Jorion, 'Value at Risk: The New Benchmark for Managing Financial Risk' (3 eds, 2009) 568. Secondary managers turned to investment products with low VaR risk profile, like credit-defaults swaps that generate small gains but only rarely have
} 
flaw is that financial managers can work in money centers worldwide, so effective regulation would need to be global.

Market realities can also increase the magnitude of these systemic shocks. For example, credit markets often provide short-term funding of long-term capital needs (which economists sometimes refer to as “maturity transformation”) because the interest rate on short-term debt is usually lower than that on long-term debt. This sacrifice of stability for lower cost can create the financial market equivalent of a bank run if, due to investor anxiety, a firm is unable to roll over, or refinance, its short-term debt. I later observe that shadow banking in particular disproportionately relies on maturity transformation.

\section{In a Changing Financial System, Regulation can Lag Reality}

Another reason why systemic shocks are inevitable is that the financial system is constantly changing. As a result, systemic risk regulation will often lag financial reality. ${ }^{15}$

Most are aware by now that future financial crises are unlikely to resemble, and may have very different causes than, past crises; thus regulatory reform can be misguided if it represents politically motivated reactions to a past crisis. That awareness, unfortunately, does not always prevent politically motivated regulation. For example, the Dodd-Frank Act focuses heavily on preventing future mortgage-lending problems because mortgage lending was at the heart of the financial crisis. Professor Anabtawi and I have observed, however, that the mortgage-lending problem itself was not special; rather, it followed a broader generic pattern that closely parallels the margin lending that was at the heart of the Great Depression. ${ }^{16}$

losses. They knew, but did not always explain to their superiors, that any losses that might eventually occur would be huge. See Conflicts and Financial Collapse, ibid n 13. 15 This time lag may be exacerbated by the increasing complexity of the financial industry and financial products. See n 40 and accompanying text.

${ }^{16}$ See Schwarcz \& Anabtawi, 'Regulating Systemic Risk', n 7, 1356-57 \& 1406-07. 
There is, however, a more subtle problem. Even otherwise salutary financial regulation is often tethered to the financial architecture - the particular design and structure of financial firms, markets, and other related institutions-existing at the time the regulation is promulgated. This type of grounded regulation has value as long as it is updated as needed to adapt to changes in the financial architecture. This helps to explain the success of the Uniform Commercial Code (UCC), a uniform-state-law statute that benefits from ongoing monitoring and updating by the non-partisan American Law Institute and the Uniform Law Commission.

But ongoing monitoring and updating can be costly and is subject to political interference at each updating stage. Without ongoing monitoring and updating, financial regulation tethered to today's financial architecture will quickly become outmoded, causing unanticipated consequences and allowing innovations to escape regulatory scrutiny. This occurred in 2008, for example, when the pre-crisis financial regulatory framework, which assumed the dominance of bank-intermediated funding, failed to adequately address a collapsing financial system in which the majority of funding had become non-bank intermediated. ${ }^{17}$

\section{Excessive Corporate Risk-taking can Trigger Systemic Shocks}

Yet another reason why systemic shocks are inevitable is that regulation does not currently — and is unlikely to, at least in the near future-adequately limit the incentives of corporate managers to engage their firms in risk-taking that could trigger systemic

\footnotetext{
${ }^{17}$ As a supplementary approach to regulating a dynamically changing financial system, I have advocated regulation that focuses also on the system's underlying, and thus less time-dependent, economic functions - the provision, allocation, and deployment of capital. See Steven L Schwarcz, 'Regulating Financial Change: A Functional Approach' (2016) 100 Minnesota Law Review <http://ssrn.com/abstract=2469467> (forthcoming) accessed 24 September 2015. Compare with Robert C Merton \& Zvi Bodie, 'A Conceptual Framework for Analyzing the Financial Environment' in Dwight B Crane et al ed, The Global Financial System: A Functional Perspective (1995) (viewing "financial innovation as driving the financial system toward the goal of greater economic efficiency”).
} 
shocks. As mentioned, excessive corporate risk-taking is widely regarded to have been a principal cause of the financial crisis. ${ }^{18}$

Regulators and policymakers have not yet systematically examined how to control excessive corporate risk-taking to limit its potential systemic consequences. Part II of this chapter addresses this issue in detail, first inquiring into the failure to prosecute managers for risk-taking that led to the financial crisis and thereafter examining how excessive corporate risk-taking should be regulated.

B. Regulation therefore Should Protect the Financial System Against the Impact of Systemic Shocks $^{19}$

Part I.A above has shown that systemic shocks are inevitable. The regulation of systemic risk therefore should include—and this Part I.B focuses on- the goal of protecting the financial system against the impact of those shocks. An obvious way to achieve that goal would be to prevent their transmission. Unfortunately, we do not yetand indeed, might never—-know enough about how systemic shocks are transmitted to prevent that.

Systemic risk regulation therefore should help to stabilize parts of the financial system afflicted by systemic shocks. ${ }^{20}$ The complexities of the financial system include not only cognitive complexity—-that things are just too complex to understand ${ }^{21}$ —but also temporal complexity—a "tight coupling" within markets in which events tend to

${ }^{18}$ See $\mathrm{n} 3$ and accompanying text.

19 This discussion is based on Steven L Schwarcz, 'Controlling Financial Chaos: The Power and Limits of Law’ (2012) Wisconsin Law Review 815; and Steven L Schwarcz \& Iman Anabtawi, 'Regulating Ex Post: How Law Can Address the Inevitability of Financial Failure' (2013) 92 Texas Law Review 75.

${ }^{20}$ This type of ex post regulation, of course, is second-best to preventing systemic shocks. The discussion below of ex post regulation is based on Schwarcz, 'Regulating Complexity in Financial Markets.'

${ }^{21}$ Compare with Steven L Schwarcz, 'Regulating Complexity in Financial Markets' (2009) 87 Washington University Law Review 211, n 15 (“[T]he more complicated a system becomes, and the more interconnected,...the odds of a breakdown in a portion of the system increases (because of complexity)[....]"). 
move rapidly into a crisis mode with little time or opportunity to intervene. ${ }^{22}$ In these ways, complexities in the financial markets resemble those found in complex engineering systems. Chaos theory, which is used to address engineering system complexity, can also inform financial system complexity. One aspect of chaos theory is deterministic chaos in dynamic systems, which recognizes that the more complex the system, the more likely it is that failures will occur. Thus, the most successful (complex) systems are those in which the consequences of failures are limited. There are at least two ways that financial regulation could accomplish this: by ensuring liquidity to systemically important firms and markets, and by requiring those firms and markets to be more internally robust. ${ }^{23}$

The extent to which regulation should require systemically important firms and markets to be more internally robust is unclear. In the case of firms, the Basel Accords, and national implementing legislation, impose capital and liquidity requirements. It may be too early, however, to assess how effective those requirements will be, or whether they might be too strict. The Basel Accords certainly failed to protect banks in connection with the financial crisis. And some argue that those types of requirements may be economically counterproductive. ${ }^{24}$

An important but only partly answered question is how regulation should require systemically important markets to be more internally robust. The primary response to

\footnotetext{
22 See Richard Bookstaber, A Demon of Our Own Design: Markets, Hedge Funds, and The Perils of Financial Innovation (Wiley 2008) 156 (applying the engineering term "tight coupling" to context of finance).

${ }^{23}$ Requiring systemically important firms to be more internally robust can also help to deter systemic shocks in the first place, by preventing such firms' failures that could trigger systemic shocks. At least existing regulatory requirements to make these firms more internally robust are more microprudential, however; they focus on protecting individual firms, as opposed to protecting the financial system per se.

${ }^{24}$ See, e.g., Eduardo Porter, 'Recession's True Cost is Still Being Tallied' New York Times (22 January 2014) at B1 $<$ http://www.nytimes.com/2014/01/22/business/economy/the-cost-of-the-financial-crisisis-still-being-tallied.html> accessed 24 September 2015 (observing that regulations that require financial institutions to increase capital cushions to buffer against risks and potential losses have been criticized for cutting into global economic output and reducing jobs).
} 
date is to provide for so-called circuit breakers to protect markets from "flash crashes," which appear to be at least partly caused by high-speed automated trading. Formal member-sponsored equity markets may also have member-provided liquidity requirements. The Dodd-Frank Act introduces another approach to making systemically important markets more internally robust. Title VIII of that Act requires the Financial Stability Oversight Council to identify systemically important financial market utilities (“SIFMUs”), subjecting them to heightened regulatory standards. SIFMUs must, among other requirements, maintain liquid assets at least equal to (a) the cost of implementing their resolution plan or (b) six-months current operating expenses, whichever is greater. They must also adopt plans addressing recovery, resolution, credit loss allocation, and recapitalization after stress events. This approach is certainly valuable, but its application to financial market utilities is limiting. Because these entities only facilitate the mechanical functions of transferring, clearing, and settling payments and securities, the approach does not help to protect market pricing. I next discuss how a liquidity provider of last resort could help to provide that protection.

Systemic risk regulation could also help to stabilize parts of the financial system afflicted by systemic shocks by ensuring liquidity to systemically important firms and markets. This effectively entails a liquidity provider of "last resort.”" 25 The Federal Reserve Bank, of course, historically served as such a liquidity provider to banks and other financial firms; however, the Dodd-Frank Act restricted its power under § 13(3) of the Federal Reserve Act to serve in that capacity, in order to limit moral hazard. I personally believe that restriction is the Dodd-Frank Act's greatest mistake.

A better way of limiting moral hazard would be to privatize at least part of any provided liquidity. For example, regulation could require systemically important firms to pay into a systemic risk fund, designed for that purpose-which, in essence, is how banks pay for their FDIC deposit insurance. Such a requirement was originally in the bill that became the Dodd-Frank Act. It was deleted, however, because certain members of

${ }^{25}$ Such a liquidity provider should provide funding only to solve temporary liquidity problems; it should not attempt to bail out insolvent firms. 
Congress felt that the very creation of a systemic risk fund would itself increase moral hazard.

To the contrary, however, such a fund should decrease moral hazard. The requirement to pay into the fund would help to internalize externalities. ${ }^{26}$ The likelihood that systemically important firms will have to make additional contributions to the fund to replenish bailout monies should motivate those firms to monitor each other and help control each other's risky behavior. ${ }^{27}$ Because their own funds would be at risk, for example, fund contributors would have incentives to inform regulators when other firms take unwise risks. ${ }^{28}$ If the required contributions to the fund are risk-adjusted, fund contributors would also have incentives to report firms that are underpaying. ${ }^{29}$

In an era of disintermediation, it is also critical to focus on providing liquidity to critical capital markets as necessary to keep them functioning. ${ }^{30}$ This task could be performed by a market liquidity provider of last resort, ideally in the form of a combined public-private enterprise. I have elsewhere explained in detail how such a liquidity provider could help to stabilize panicked financial markets, without creating moral hazard. ${ }^{31}$ In brief, a market liquidity provider could either choose to purchase market securities, at a price deeply discounted from the original market price and also much lower than the estimated intrinsic value of the securities purchased but still high enough

\footnotetext{
26 This type of regulation ideally should be global to avoid prejudicing the competitiveness of firms subject to U.S. regulatory requirements.

27 See Schwarcz, 'Controlling Financial Chaos' (n 19).

${ }^{28}$ Jeffrey N Gordon \& Christopher Muller, 'Confronting Financial Crisis: Dodd-Frank’s Dangers and the Case for a Systemic Emergency Insurance Fund' (2011) 28 Yale Journal on Regulation 156 (calling for a systemic emergency insurance fund that is funded by the financial industry).

${ }^{29}$ ibid.

30 Steven L Schwarcz, 'Markets, Systemic Risk, and the Subprime Mortgage Crisis' (2008) 61 Southern Methodist University Law Review 212.

${ }^{31}$ See, e.g., Steven L Schwarcz, 'Too Big To Fail?: Recasting the Financial Safety Net', Lawrence E Mitchell \& Arthur Wilmarth, Jr, eds, in The Panic of 2008 (2010).
} 
to stabilize market prices above the panicked free-fall level. ${ }^{32}$ Alternatively, a market liquidity provider could attempt to stabilize the market by entering into derivatives contracts to strip out risks that the market has the greatest difficulty hedging-in effect, the market's irrationality element—-thereby stimulating private investment. By hedgingand not actually purchasing securities directly — the market liquidity provider would appear to be taking less investment risk, and thus its function may be seen as more politically acceptable. ${ }^{33}$

By providing a lifeline to financial institutions, a lender of last resort can foster "moral hazard” by encouraging these entities to be fiscally reckless. In contrast, a market liquidity provider, especially if it acts at the outset of a market panic, ${ }^{34}$ can profitably invest in securities at a deep discount from the original market price and still provide a floor to how low the market will drop. ${ }^{35}$ Buying at a deep discount will mitigate investor moral hazard. Furthermore, by focusing on markets, a market liquidity provider can minimize the too-big-to-fail dilemma faced by a lender of last resort to institutions. By stabilizing markets, the likelihood of firm-level failure is diminished, thereby reducing the incidences in which a lender of last resort to institutions is needed. In economic terms, therefore, any safety-net subsidies created by a marker liquidity provider of last resort should be much smaller than those created by a lender of last resort.

\footnotetext{
32 Say, for example, that the intrinsic value of a type of mortgage-backed securities (or "MBS") is estimated to be in the range of 80 cents on the dollar. If the market price of those securities had fallen significantly below that number, say to 20 cents on the dollar, the market liquidity provider could purchase these securities at, say, 60 cents on the dollar, thereby stabilizing the market and still making a profit. To induce a holder of the mortgage-backed securities to sell at that price, the market liquidity provider could, for example, agree to pay a higher "deferred purchase price" if the securities turn out to be worth more than expected.

${ }^{33}$ Compare with Floyd Norris, 'U.S. Bank Bailout to Rely in Part on Private Money' New York Times (9 February 2009) A1 (observing that having the government purchase the distressed MBS securities directly would be a "politically perilous course.”)

${ }^{34}$ The timing of purchases will be critical. The market liquidity provider should try to act at the outset of a market panic, before market prices collapse too far. On the other hand, the market liquidity provider should be careful not to act when price fluctuations are normal.

35 The market liquidity provider, and therefore taxpayers, would profit by buying securities at a much lower price than their intrinsic value.
} 
In summary, systemic shocks are inevitable. Regulation therefore should be designed not only to try to reduce those shocks but also to protect the financial system against their unavoidable impact. This could be done by applying chaos theory to help stabilize the financial system. I next focus on trying to prevent excessive corporate risktaking, which is one of the leading triggers of systemic shocks and widely regarded to have been a principal cause of the financial crisis.

\section{Perspectives on Regulating Excessive Corporate Risk-Taking, A}

\section{LEAdiNg TRIgGer OF SYSTEMIC SHOCKS}

Agency theory suggests that targeting managers in their personal capacity would be an optimal deterrent to excessive corporate risk-taking. Yet few managers have been prosecuted for the excessive corporate risk-taking that led to the financial crisis. Part II.A shows why managerial prosecution is not-and is unlikely to become-a credible deterrent. Thereafter, Part II.B examines how else excessive corporate risk-taking could, and should, be regulated.

A. Why Have So Few Managers been Prosecuted for Excessive Corporate Risktaking that Led to the Financial Crisis? ${ }^{36}$

To understand why post-financial crisis prosecution has focused so heavily on firm-level liability, and not personal liability, consider the changes that may be impeding the imposition of personal liability for excessive corporate risk-taking.

\section{Systemic Risk is Complicating What Risk-Taking is 'Excessive'}

Until the financial crisis, it seemed relatively easy to identify excessive corporate risk-taking by taking into account the consequences of corporate risk-taking on investors,

\footnotetext{
36 This discussion is based on Schwarcz, 'Excessive Corporate Risk-Taking and the Decline of Personal Blame' (n 2).
} 
primarily shareholders. Because of its potential for widespread public harm, systemic risk is complicating that analysis.

What constitutes “excessive” risk-taking depends on the observer. Risk-taking is excessive from a given observer's standpoint if it has a negative expected value to that observer. Thus, it is reasonable to assume that investors would oppose risky business ventures that have a negative expected value to them. The problem, however, is that systemically important firms can engage in risk-taking ventures that have a positive expected value to their investors but a negative expected value to the public. That's because much of the systemic harm from such a firm's failure would be externalized ${ }^{37}$ onto other market participants as well as onto ordinary citizens impacted by an economic collapse.

This misalignment occurs because the expected value of corporate risk-taking is traditionally viewed only from the standpoint of a firm's investors. That perspective ignores (non-investor) externalities caused by the risk-taking. Because myriad externalities result from corporate risk-taking, it would not be feasible to take all those externalities into account in regulating risk-taking. But systemic externalities that harm the real economy should be taken into account.

Until systemic externalities are required to be taken into account, managers who engage their firms in risk-taking that has potentially systemic consequences may not at the time be engaging in legal wrongdoing.

\section{Decisionmaking is Becoming More Decentralized}

Another reason for the decline of personal liability may be the increasingly decentralized nature of decisionmaking at large financial services firms, which makes it

37 This could be described as a type of "tragedy of the commons," insofar as market participants suffer from the actions of other market participants. But it also is a more standard externality insofar as non-market participants (i.e., the ordinary citizens impacted by an economic collapse) suffer from the actions of market participants. 
difficult to assign personal liability for excessive risk-taking. Senior executives do not even get involved in the design of potentially risky financial products, such as collateralized debt obligations (“CDO”s).

Former Attorney General Holder has intimated that this decentralized decisionmaking is intended to protect managers from personal liability. ${ }^{38}$ In reality, though, it may well be intended to maximize corporate efficiency and innovation. Decentralization is said to (i) encourage motivation and creativity; (ii) allow many minds to work simultaneously on the same problem; and (iii) accommodate flexibility and individualization. ${ }^{39}$ Business scholars also argue that decentralized decisionmaking is necessary in a globalized economy, providing firms with much needed flexibility to deal with rapidly changing market conditions.

Whatever the intention, a side-effect of decentralized decisionmaking is to make it more difficult to assign risk-taking responsibility, and thus to impose personal liability for excessive risk-taking.

\section{The Law Increasingly is Lagging Financial Innovation}

Another change is that the law increasingly lags financial innovation as the financial industry and financial products become more complex. Even when regulators acquire industry information, it may be of only limited relevance to the current situation. The increasing income disparity, now more than two-to-one, between financial industry employees and their government regulatory counterparts ${ }^{40}$ may also be lengthening that

\footnotetext{
38 Attorney General Eric Holder, 'Remarks on Financial Fraud Prosecutions at NYU School of Law' (2014) <http://www.justice.gov/opa/speech/attorney-general-holderremarks-financial-fraud-prosecutions-nyu-school-law $>$ ("[C]orporations are structured to blur lines of authority and prevent responsibility for individual business decisions from residing with a single person.”).

39 Thomas W Malone, 'Making the Decision to Decentralize' (2004) Harvard Business School- Working Knowledge for Business Leaders.

${ }^{40}$ Steven L Schwarcz, 'Intrinsic Imbalance: The Impact of Income Disparity on Financial Regulation’ (2015) 78 Law and Contemporary Problems 97.
} 
time lag by making it more difficult for financial regulators to understand and process complex information once obtained.

Because of the time lag, many risky actions by financial firms will not be illegal when taken. Therefore, the executives who determine and manage those actions will not be acting illegally at the time.

\section{Systemic Harm is Limiting Proof of Causation}

Another change impeding the imposition of personal liability for excessive risktaking is that the primary harm now caused by financial failure-systemic harm-limits the application of tort law. Tort law, which is part of what Judge Richard Posner calls public control through the common law system of privately enforced rights, has long been a fundamental tool to impose personal civil liability to remedy harm for unreasonable risk-taking. Its utility is limited, however, to remedying foreseeable harm. But systemic harm is rarely foreseeable.

Systemic harm instead affects a wide range of third parties in unpredictable ways. Consider, for example, an individual who is forced to close her family-owned restaurant during a systemically caused recession. Or taking a more concrete example from the financial crisis, consider whether to impose tort liability on a manager of a financial firm who, in the expectation of a bonus, sells risky ABS CDO securities to investors, contributing to that crisis. Tort law could not—and probably should not—be used to impose personal liability on that manager for the resulting systemic harm.

\section{Shrinking of Resources is Tightening Prosecutorial Risk-Reward Assessment}

Like everyone else, prosecutors have limited resources. Since the terrorist attacks of September 11, 2001, several government agencies that investigate the financial industry have lost resources to anti-terrorism investigations. And since the Madoff fraud, the SEC has concentrated on Ponzi-like schemes, further diverting resources. 
Being under pressure to spend their resources for maximum impact, prosecutors are choosing to prosecute clear-cut fraud cases. They also are choosing to prosecute firms, not individuals. Firms are much more likely to settle, or to enter into deferred prosecution agreements, ${ }^{41}$ as a cost of doing business.

Moreover, pursuing individuals can be very costly. For example, the rate of successful prosecutions of individuals is very low. Some believe this reflects a selfreinforcing trend: as prosecutors spend less time engaged in actual litigation, their trial skills can diminish. Juries are also more reluctant to hold individuals liable. At least in part because of these costs, personal liability is now rarely pursued in complex financial cases, and then primarily through civil settlements that do not admit wrongdoing.

For the reasons explained above, the prosecution of corporate managers for excessive risk-taking is unlikely, under our existing regulatory framework, to be successful. Part II.B next examines how else that risk-taking could, and should, be regulated.

\section{B. How Else Could Excessive Corporate Risk-taking be Regulated?}

I next consider five alternative methods of regulating excessive corporate risktaking. First, I show why imposing firm-level liability is not a credible deterrent. Second, I examine whether there should be a managerial duty to the public. Third, I suggest that the principle of limited liability should be reexamined in the context of shadow-banking firms. Fourth, I explore the concept of ring-fencing, or cordoning off, risky ventures. Finally, I consider so-called “Too Big to Fail” (TBTF) regulation.

\footnotetext{
${ }^{41}$ A deferred prosecution agreement, or "DPA," is a contractual arrangement between a firm and the government that enables the firm to avoid prosecution in return for agreeing to act responsibly in the future.
} 


\section{Imposing Firm-level Liability is Not a Credible Deterrent ${ }^{42}$}

Being managed by individuals, firms themselves are only second-best targets of deterrence. ${ }^{43}$ Although numerous firms have been fined very substantial amounts for activities related to the financial crisis, ${ }^{44}$ some experts view these fines, from the perspective of multiple-year corporate earnings, as simply the "cost of doing business." 45 Firm-level liability can also inadvertently harm third parties, such as the prosecution of accounting giant Arthur Andersen which caused tens of thousands of employees to lose

42 This discussion is based on Schwarcz, 'Excessive Corporate Risk-Taking and the Decline of Personal Blame' (n 2).

${ }^{43}$ See, e.g., Claire A Hill \& Richard W Painter, 'Why SEC Settlements Should Hold Senior Executives Liable’ New York Times (29 May 2012)

$<$ http://dealbook.nytimes.com/2012/05/29/why-s-e-c-settlements-should-hold-seniorexecutives-liable/> accessed 24 September 2015 (arguing that when penalties are assessed only against an entity, the individuals responsible have little incentive to change their behavior; and thus, in order to change that incentive, individuals should also be personally liable); Clair Hill \& Richard W Painter, 'Berle’s Vision Beyond Shareholder Interests: Why Investment Bankers Should Have (Some) Personal Liability’ (2010) 33 Seattle University Law Review 1173 (arguing that high-level bankers should be held personally liable).

${ }^{44}$ See, e.g., Richard McGregor \& Aaron Stanley, 'Banks Pay Out \$100bn in U.S. Fines' Financial Times (25 March 2014) <http://www.ft.com/cms/s/0/802ae15c-9b50-11e3946b-00144feab7de.html\#axzz3Eds2zwdl> accessed 24 September 2015 (quoting Tony Fratto of Hamilton Place Strategies as stating that the fines were "very substantial”). ${ }^{45}$ McGregor \& Stanley, ibid (quoting Professor Anat Admati of Stanford University Knight School of Business). Professor John Coffee similarly claims that "the SEC is settling cheaply with entities and ignoring individuals-a policy of parking tickets for securities fraud.” See John C Coffee, 'Securities Enforcement: What Has Happened? Why are Folks Upset? What Can Be Done?' (Columbia University Law School First Annual Securities Regulation and Enforcement Institute, New York City, 2012). 
their jobs. Targeting managers in their personal capacity is widely viewed as a greater, ${ }^{46}$ if not also a more optimal, ${ }^{47}$ deterrent to corporate risk taking than firm-level liability.

Many nonetheless view firm-level liability as a valuable deterrent when it is imposed through deferred prosecution agreements (DPAs). Assistant Attorney General Breuer has argued, for example, that firm-level DPAs can bring large settlements and oversight that can have great punitive and deterrent effect. He explains that a deferred prosecution agreement is a powerful tool because

when a company enters into a DPA with the government . . . it almost always must acknowledge wrongdoing, agree to cooperate with the government's investigation, pay a fine, agree to improve its compliance program, and agree to face prosecution if it fails to satisfy the terms of the agreement. All of these components of DPAs are critical for accountability. ${ }^{48}$

Professor Arlen also observes that a DPA can incentivize firms to monitor, police, and deter crime by creating or improving internal compliance programs under

\footnotetext{
${ }^{46}$ See, e.g., Mary Jo White, U.S. SEC Chair, 'Deploying the Full Enforcement Arsenal' (Council of Institutional Investors Fall Conference, Chicago, 2013) <http://www.sec.gov/News/Speech/Detail/Speech/1370539841202\#.VE7m_iJ4pK4> accessed 24 September 2015 (observing two reasons for this greater deterrence: that economic actions taken against individuals not only require them to pay out of their only pockets but also impose reputational costs - a form of shaming - causing the individuals to lose social standing). The reputational costs might also include, of course, the inability to continue working in the financial sector.

47 Some argue that adding the threat of personal liability to the threat of firm-level liability should be the optimal deterrent. See, e.g., Cedric Argenton, Eric van Damme, \& Sigrid Suetens, 'Optimal Deterrence of Illegal Behavior Under Imperfect Corporate Governance’ (2014) European Economic Association \& Econometric Society 1 $<$ http://www.eea-esem.com/files/papers/EEAESEM/2014/2301/collusion\%20under\%20agency\%20theory\%2020140123.pdf> accessed 24 September 2015 (arguing that personal liability is needed in addition to firmlevel liability to reach the optimal level of deterring corporate moral hazard); A Mitchell Polinsky \& Steven Shavell, 'Should Employees Be Subject to Fines and Imprisonment Given the Existence of Corporate Liability?’ (1993) 13 International Review of Law and Economics 239, 246-48.

${ }^{48}$ Lanny A Breuer, Assistant Attorney General for the Criminal Division, U.S. Department of Justice, 'The Role of Deferred Prosecution Agreements in White Collar Criminal Law Enforcement' (The Association of the Bar, New York, 2012).
} 
the threat of firm-level sanctions. ${ }^{49}$

But the fact that firm-level liability in the form of DPAs can be a valuable deterrent does not prove it is a sufficient deterrent. Some question whether DPAs provide adequate sanctions. ${ }^{50}$ Others question whether firms always comply with them. Professor Brandon Garrett has found, for example, that at least eight large banks have continued since 2001 to engage in actions prohibited by the DPAs. ${ }^{51}$

It also is uncertain whether prosecutors would attempt - and if they did, whether they legally would have the right — to apply DPAs to deter excessive corporate risktaking, even risk-taking that results in systemic harm. DPAs are normally applied only to deter crime and other illegal actions. Excessive corporate risk-taking, however, is not (and should not necessarily be) illegal. It therefore remains uncertain whether firm-level liability, even in the form of DPAs, is a sufficient deterrent to control and internalize the costs of excessive corporate risk-taking.

\section{Should there be a Public Governance Duty? ${ }^{52}$}

49 Jennifer Arlen, 'Corporate Criminal Liability: Theory and Evidence’ (2012) NYU Center for Law, Economics and Organization, Law \& Economics Research Paper Series: Working Paper No 11-25, 169. Compare with Wulf A Kaal \& Timothy A Lacine, 'The Effect of Deferred and Non-Prosecution Agreements on Corporate Governance: Evidence from 1993-2013' (2014) 70 Business Lawyer 61 (arguing that deferred and nonprosecution agreements have increased substantially in recent years and have led to broad changes and improvements to corporate governance).

${ }^{50}$ See, e.g., Mike Koehler, 'The Foreign Corrupt Practices Act Under the Microscope'(2012) 15 University of Pennsylvania Journal of Business Law 1 (DPAs "allow egregious instances of corporate conduct to be resolved too lightly. Because the government does not file actual charges to which the company must plead, such conduct is often resolved without adequate sanctions and without achieving maximum deterrence.”).

${ }^{51}$ Brandon L Garrett, Too Big to Jail: How Prosecutors Compromise With Corporations (Belknap Press 2014). Garrett further observes that the DPAs implemented from 2001 to 2012 have been largely ineffective due, in part, to fines that have lacked any meaningful impact.

52 This discussion is based on Steven L Schwarcz, 'Keynote Reflections: The Public Governance Duty’ (2015) 50 Georgia Law Review 1 (2015)

$<$ http://ssrn.com/abstract=2585551> accessed 24 September 2015. It also is based on my 
As discussed, there is a fundamental misalignment between the risk-taking interests of individual market participants and societal interests in controlling systemic harm. ${ }^{53}$ One regulatory response has been the post-crisis prosecution of systemically important firms for excessive risk-taking. But this response has been inadequate for several reasons, including that, being managed by individuals, firms themselves are second-best targets of deterrence, and firm-level liability can inadvertently harm third parties. $^{54}$

To better control systemic risk, excessive corporate risk-taking should be regulated at the managerial level. But what would it mean to prosecute managers for excessive corporate risk-taking? The threshold problem is that, as mentioned, systemic risk is complicating what that concept means. ${ }^{55}$ A systemically important firm may well decide to engage in a transaction that is expected to be profitable-and thereby favorable to its investors and thus appropriate corporate risk-taking under existing corporate governance law - even though doing so could increase systemic risk, since much of the harm from a resulting systemic collapse would be externalized onto other market participants as well as onto ordinary citizens impacted by an economic collapse. ${ }^{56}$

Because corporate risk-taking can impact the public in addition to impacting investors, one way of controlling excessive risk-taking would be to require the managers of a systemically important firm to run the firm as agents not merely for the investors but also for the public. To that extent, such managers would not only have a private corporate governance duty to investors but also a "public governance duty" to society not to engage in excessive risk-taking that could systemically harm the public. ${ }^{57}$

forthcoming article, 'Misalignment: Corporate Risk-Taking and Public Duty' <http://ssrn.com/abstract=2644375> accessed 24 September 2015.

53 See $n 37$ and accompanying text.

54 See nn 43-47 and accompanying text.

55 See Part II.A.

${ }^{56}$ See $\mathrm{n} 37$ and accompanying text.

57 See Schwarcz, 'Misalignment: Corporate Risk-Taking and Public Duty’ (n 55). Some argue that a fiduciary duty to the public is already required under Canadian law, after BCE Inc. v. 1976 Debentureholders, [2008] 3 S.C.R. 560 (Can.), in which the court stated 
By explicitly taking into account systemic risks to the public, this public governance duty would go much further, for example, than the duty of existing corporate risk committees. Even the Dodd-Frank Act risk-committee mandate at most indirectly suggests that risk committees consider the public interest. ${ }^{58}$

This reformulation of corporate governance law raises several practical questions: (1) How should a public governance duty be legally imposed?; (2) How should managers assess the public costs and private benefits of a risk-taking activity?; (3) How should managers balance those costs and benefits when deciding whether the firm should engage in a given risk-taking activity?; (4) How should a public governance duty be enforced?; (5) Weighing the goals of protecting the public against systemic externalities and encouraging the best people to serve as managers, to what extent should managers performing their public governance duty have the protection of a business judgment rule as a defense to liability?; (6) To what extent should managers be protected under D\&O liability insurance? I attempt to answer these questions in a separate article. ${ }^{59}$

that " $[\mathrm{w}]$ here conflicting interests arise, it falls to the directors of the corporation to resolve them in accordance with their fiduciary duty to act in the best interests of the corporation. ... There are no absolute rules and no principle that one set of interests should prevail over another. In each case, the question is whether, in all the circumstances, the directors acted in the best interests of the corporation, having regard to all relevant considerations, including — but not confined to - the need to treat affected stakeholders in a fair manner, commensurate with the corporation's duties as a responsible corporate citizen.”

58 This mandate, promulgated in Federal Reserve Regulation YY, requires that systemically important firms form a risk committee chaired by an independent director and have a member with “risk-management expertise comparable to the company's structure, risk profile, complexity, activities, [and] size.” It also mandates (emphasis added) that "The level of risk management expertise possessed by the risk committee of a company should rise in accordance with a company's rising threat of systemic risk to the economy." It does not, however, specifically require the committee to take systemic risk to the economy into account. See 12 CFR § 252.20-22, 30-35 (2015), part of Regulation YY promulgated by the Federal Reserve to carry out $\S 165(\mathrm{~h})$ of Dodd-Frank Wall Street Reform and Consumer Protection Act (Pub L 111- 203, HR 4173) (Dodd-Frank)..

59 See Schwarcz, 'Misalignment: Corporate Risk-Taking and Public Duty’ (n 55). 
3. Should Limited Liability Remain the Norm, Especially for Shadow-Banking Firms $?^{60}$

Narrowing limited liability for at least certain firm managers can limit conflicts that encourage excessive risk-taking. Corporate limited liability protects a firm's equity investors from the firm's liabilities, except for the capital invested. Although limited liability can create moral hazard, leading to excessive corporate risk-taking, it also encourages equity-capital investment by addressing investor risk aversion. Empirically, scholars have been uncertain how those factors should be balanced.

That balance shifts radically, however, in the context of shadow banking. (Shadow banking is a loose term that refers to the decentralized provision of financing outside of traditional banking channels, and thus without the need for traditional modes of bank intermediation between capital markets and the users of funds.) For two reasons, limited liability can be a uniquely fertile source of systemic externalities for shadowbanking firms.

First, managers of shadow-banking firms are likely to take greater risks than managers of other limited liability firms. The relatively small firms, such as hedge funds, that operate in the shadow-banking system are often managed directly by their primary investors. Because such investor-managers typically are entitled to a significant share of their firm's profits, they have strong incentives to take high risks that could generate outsized profits. Yet if a risky action exposes their firm to significant liability for externalized harm, limited liability protects those investor-managers from losing more than their invested capital. This is radically unlike the management incentives in nonshadow banking firms, in which senior managers tend to share only indirectly in profits, such as through stock options.

\footnotetext{
60 This discussion is based on Steven L Schwarcz, 'The Governance Structure of Shadow Banking: Rethinking Assumptions About Limited Liability’ (2014) 90 Notre Dame Law Review 1 <http://ssrn.com/abstract=2364126> accessed 24 September 2015.
} 
Even more significantly, the failure of a shadow-banking firm is more likely than that of a non-bank to have systemic consequences. Like traditional banks, shadowbanking firms engage in financial intermediation on which the real economy is dependent. Because all financial intermediaries—including shadow-banking firms and traditional banks - tend to be highly interconnected, the failure of a shadow-banking firm could trigger the failures of other financial intermediaries. Such a chain of failures would be the epitome of a systemic event, especially if it materially reduces the availability of financial intermediation. Additionally, shadow banking's disproportionate reliance on short-term funding of long-term projects not only increases the likelihood of a shadowbanking firm's failure but also can increase the systemic consequences of that failure. Economists have identified the failure of shadow-banking firms to roll over short-term debt as a contributing factor to the recent financial crisis. ${ }^{61}$

A potential solution to this problem is to impose personal liability on investormanagers with the power to "control" shadow-banking firms by narrowing their limited liability protection — perhaps to double liability or some other multiple of their investment. This would not be unfair to shareholders because it would only impact those in a capacity to control the firm. And it should not unduly discourage equity-capital investment. Even if they are risk averse, owner-managers with the power to control their firms could choose to govern to minimize their potential liability (and the liability of those owner-managers would not be open-ended but limited to, e.g., double-liability).

\section{Should Ring-fencing be used to Control Corporate Risk-taking? ${ }^{62}$}

"Ring-fencing" is often touted as a potential regulatory way to control risk in banking, finance, public utilities, and insurance. The United Kingdom has been ring-

${ }^{61}$ Sandra C Kreiger, Executive Vice President, New York Federal Reserve Bank, 'Reducing the Systemic Risk in Shadow Maturity Transformation' (Global Association of Risk Professionals $12^{\text {th }}$ Annual Risk Management Convention, 2011) <http://www.newyorkfed.org/newsevents/speeches/2011/kri110308.html> accessed 24 September 2015.

${ }^{62}$ This discussion is based on Steven . Schwarcz, 'Ring-Fencing' (2013) 87 Southern California Law Review $69<$ http://ssrn.com/abstract=2228742> accessed 24 September 2015. 
fencing banks by legally separating certain of their risky assets from their retail banking operations. Regulators in the United States have been considering ring-fencing systemically important financial institutions (SIFIs), including banks, to reduce systemic risk. The "Volcker Rule" is also a form of ring-fencing in that it prohibits systemically important firms from conducting activities viewed as risky, such as running a private equity fund. Congress has been considering enacting a ring-fencing scheme proposed in federal “covered bond” legislation, which would parallel European ring-fencing of certain secured transactions. State regulators often require the ring-fencing of utility companies by legally separating their risky assets and operations from the public-utility function. And the National Association of Insurance Commissioners (NAIC) has been proposing the increased ring-fencing of insurance companies.

But what is "ring-fencing”? Because it is proposed in different contexts as a solution to different problems, ring-fencing is inconsistently defined; and even within a given context, it is often ill-defined. By examining its functions, ring-fencing can be understood as legally deconstructing a firm in order to more effectively reallocate and reduce risk. The deconstruction can occur in various ways. For example, the firm could be made more internally viable, such as by separating risky assets from the firm, preventing the firm from engaging in risky activities or investing in risky assets, and ensuring that the firm is able to operate on a standalone basis even if its affiliates fail. The firm could also be protected from external risks, such as third-party claims, involuntary bankruptcy, and affiliate abuse. ${ }^{63}$

Consider whether systemically important financial institutions (SIFIs) should be ring-fenced. Ring-fencing can apply to SIFIs in two ways: by protecting the publicly beneficial activities, if any, performed by SIFIs; and by protecting against the failure of

\footnotetext{
63 There are many practical questions associated with ring-fencing. For example, which firms should be subject to ring-fencing? Which "risky" assets should be separated from the firm, and how should that separation occur? Which "risky" activities and asset investments should the firm not engage in, and how should that engagement be prevented? Which affiliate "risks" should the firm be protected from, and how should that protection be implemented?
} 
SIFIs that are so large and contractually interconnected with other SIFIs (including banks) that their failure could trigger a systemic collapse. First examine whether ringfencing should be used to protect the publicly beneficial activities performed by bankSIFIs. Then examine non-bank SIFIs.

The need to ring-fence banks would certainly not be as strong, for example, as the need to ring-fence public utilities. Public utilities not only provide critical services such as power, clean water, and communications but are also typically monopolies - and hence the only entities able to provide these services. Ring-fencing the utility helps assure the continuity of those services. In contrast, the market for banking services, at least in the United States (in contrast to the U.K.), is competitive. If some risky banks become unable to provide critical services, other banks should be able to provide substitute services.

The argument that ring-fencing should be used to protect the publicly beneficial activities performed by non-bank SIFIs is therefore even more dubious. As a result of disintermediation, non-bank SIFIs have begun to perform at least some financial intermediation services that previously were performed by banks. It does not appear, however, that any of those services are of the type that should justify ring-fencing. Nonbank SIFIs do not take deposits, and, at least in the U.S., they are legally restricted from doing so. Non-bank SIFIs do not operate payments systems. The only traditional banking activity that non-bank SIFIs are performing is the intermediation of credit, by providing financing to business. Although this activity is beneficial to the public, there is no evidence suggesting that ring-fencing regulation is needed to protect it. A wide range of non-bank firms engage in disintermediated financing, and those that find aspects of ringfencing desirable as a business matter are already able to contractually ring-fence themselves.

\section{Should Regulation Limit Too-Big-to-Fail Firms?}

Another potential way to regulate excessive risk-taking is to limit the chance that so-called too-big-to-fail (“TBTF”) firms will engage in risky projects without worrying 
about failing, since managers of these firms know, or at least believe, that the government would never let the firms fail. As mentioned, the Dodd-Frank Act restricts the Federal Reserve's power to bail out firms, in order to limit such morally hazardous behavior. TBTF regulation also focuses on reducing the TBTF nature of systemically important firms, exemplified by the Dodd-Frank Act's requirement that systemically important firms must file so-called living wills, setting forth how they could liquidate with minimal systemic impact. $^{64}$

I am somewhat skeptical of TBTF regulation. As observed, restricting the Fed's power to bail out failing firms is likely to increase systemic risk. I also question the efficacy of the living-will requirement. In my many years as a workout and bankruptcy lawyer, I rarely saw a firm’s failure that accurately reflected, much less closely resembled, expectations about the firm when it was profitable. Living wills also do not prevent the concurrent failure of multiple otherwise-TBTF firms from, collectively, having a systemic impact; the financial crisis demonstrated that such a concurrence is likely when the causes of the failures are interconnected.

\section{CONCLUSION}

Systemic shocks are inevitable. Regulation should therefore be aimed at protecting the financial system from the impact of those shocks. Regulation also needs to focus on reducing a leading, but under-theorized, source of systemic shocks: the incentives of corporate managers to engage their firms in excessive risk-taking. Although it may not be feasible to reduce those incentives by prosecuting managers for that risk taking, there are several regulatory alternatives. This chapter argues that at least two of

\footnotetext{
${ }^{64}$ TBTF regulation and the regulation of systemically important firms to make them more internally robust (and thereby better able to absorb systemic shocks) also overlap, such as regulation imposing capital and liquidity requirements. I have already addressed that other regulation. See nn 23-25 and accompanying text (discussing the extent to which regulation should require systemically important firms to be more internally robust, including imposing capital and liquidity requirements).
} 
these alternatives — mandating a public governance duty, and narrowing limited liability protection for owner-managers of shadow-banking firms - are especially worth pursuing. 